\title{
Transformation of the Personnel Training System for the New Economy
}

\author{
Tatyana L. Sergeeva 1[ORCID 0000-0001-6818-0405], \\ Dinara R. Amirova 2*[ORCID 0000-0001-9698-6764]
}

\author{
${ }^{1}$ Yaroslav-the-Wise Novgorod State University, Veliky Novgorod, Russia \\ ${ }^{2}$ Penza State University of Architecture and Construction, Penza, Russia \\ amirova_dina@mail.ru
}

\begin{abstract}
Currently, digital transformation has affected all areas of the country's public life and continues to cover all processes, all organizations and the entire population. It involves changing not only the technological structure, the established forms of doing business, but also the ways in which people interact in general. The new (digital) economy also reveals the need for new digital competencies among staffers, specialists in completely different fields. The most important feature of modern personnel in demand in the digital economy is the effective use of information and communication technologies in everyday and professional activities, as well as digital literacy. The authors link digital skills with the successful implementation of the state innovation policy. They provide a comprehensive study of the category of digital competence, from the standpoint of different scientific approaches. An attempt was made to systematize and substantiate the skills and abilities necessary for personnel in the context of the digital transformation of the economy, including: innovative thinking, the ability to generate new ideas, a creative approach to solving problems and tasks, analytical thinking and digital competencies. The factors influencing the formation of personnel for the new economy are considered, including: state policy in the field of education, science, innovation, the needs of the business community, etc. The main goals and priorities of the state policy in the field of digitalization and training of qualified personnel are reflected, taking into account the needs of the modern economy. The main trends in the training of competent and highly qualified personnel for the digital economy, capable of using information and communication technologies in the workplace at a qualitatively new level, are revealed. A statistical analysis of the level of formation of some digital skills among personnel in the real economy of Russia is presented in comparison with foreign countries. It is substantiated that the current trend in personnel training once again emphasizes the importance of continuous learning and the acquisition of digital skills to accelerate the pace of digitalization of the Russian economy.
\end{abstract}

Keywords: digital transformation, innovations, digital competencies, digital skills and abilities, personnel for the new economy, state innovation policy, indicators of the information society

\section{INTRODUCTION}

The trends of recent years indicate the global dependence of almost all spheres of public life on innovation and digital technologies, as well as the creation of new markets and business models using information and communication technologies (hereinafter - ICT). Today, almost the whole world is increasingly using digital technologies, and with the advent of the Internet, companies are increasingly transferring communication to the virtual space - the Internet, where a person spends a lot of time.
The following changes are observed in the development of the economic life of society: the network form of coordination and interaction of economic entities becomes a priority, an orientation towards the introduction of innovations appears, human capital and information become the main factors of competitiveness in the national economy [1].

Digital breakthroughs in technology, the economy and the organizational sphere in the $21^{\text {st }}$ century have radically changed the way people work, consume and communicate [2]: production 
and business, science and education, services are becoming more and more digitized.

The new economy not only opens up new opportunities, but also significantly affects the effectiveness of innovative practices in all sectors and industries, due to:

- big data analytics, instant processing and transmission of any information at any distance;

- business process modeling, which, in turn, contributes to the commercialization of innovative products;

- the use of new methods and ways of interaction between economic agents;

- automation of production processes;

- the availability of the results of innovative activities to users (business partners, customers, consumers), including through information support;

- the technological capabilities of modern business, which shapes its environment, increasing efficiency and simplifying the ordinary life of citizens, through the promotion of e-commerce, etc.

Thus, according to the Organization for Economic Co-operation and Development (OECD), e-commerce has already significantly changed the usual, traditional distribution channels for many categories of goods.

For example, in 2018, common items purchased online (averaging around $40 \%$ of total sales) included clothing, footwear, sporting goods, travel products, event tickets, reading materials, movies and music, and others [3]. Moreover, at present, for many companies, digital technologies are becoming a driving force, they are a source of income and development of new markets.

In Russia in 2015, an average of $26.7 \%$ of the population across the country used the Internet to order goods and services, in 2019 - 41.7\%. According to the Association of e-commerce companies, the share of the local e-commerce market in Russia as a whole in 2020 increased to $86 \%$, while cross-border trade accounted for $14 \%$ (in 2019, these values were $71 \%$ and $29 \%$, respectively).

However, this increase can be easily explained: it was observed around the world in connection with the spread of COVID-19.

\section{MATERIALS AND METHODS}

The purpose of the study conducted by the authors of the article is to analyze the trends and conditions for the development of skills necessary for the digital society, the factors influencing the formation of digital competencies, as well as identifying the problems that the new economy faced in the process of training personnel and formulating acceptable options for their solution.

The methodological basis of the study was a comprehensive approach based on the principle of the unity of theory and practice and including modern methods of statistical and comparative analysis.

\section{RESULTS}

At present, the use of ICT has become the norm for all spheres of society: in the workplace; in the educational process, teaching and learning; in the field of trade; in everyday life. The consequences of using digital technologies are large-scale:

- transformation of the education system (elearning);

- workplace transformation: many organizations have successfully transformed the workplace through the transition to remote working;

- transformation of business processes, organization of online trading, negotiation, conclusion of transactions, etc.

The effective use of digital technologies in the new economy for various areas and purposes also reveals the need to acquire relevant competencies, develop new skills both for organizing work and management, and for the education system itself, which allows them to be developed.

There is no doubt about the complementarity of digital and innovative skills, as any innovation requires their implementation, and to go beyond inventions, further practical implementation or application requires digital technologies. They open up opportunities for promoting products, increasing the efficiency of production processes, including through their automation, for coordinating the interconnection of supply chains, for improving interaction with business partners and with end consumers.

Digital innovation can be found in every sector. They include innovations in products or processes 
that are associated with ICTs, as well as innovations that rely heavily on ICTs for their development or implementation. A wide range of innovations in business processes can lead to fundamental changes in the organization's ICT functions and their interaction with other business functions and delivered products [4].

Digitalization is turning from a simple method of converting information into a digital form into a key factor in business prosperity, as well as a driver of economic and global social development.

Under the influence of digitalization, the content of many professions is significantly transformed [5]. It is clear that today and in the coming years, the demand for ICT skills in the workplace will only increase. Currently, the economy needs personnel capable of generating new ideas, effectively using ICT, implementing them in the workplace, and quickly adapting to technological and structural changes taking place in society.

The formation of relevant competencies that meet the needs of the new economy is reflected as key tasks in the program "Digital Economy of the Russian Federation" [6]:

- formation and implementation of requirements for the basic competencies of the digital economy in the education system;

- increasing the number of graduates with competencies in the field of ICT;

- increasing the share of the population with digital skills;

- formation of the basic competencies of the digital economy among civil servants or employees of state companies.

The success of any specialist in professional activities in the conditions of informatization of society will depend on the ability to function in the "information field", on the level of formation of his digital competencies and skills [7].

Since digitalization covers all types of activities, it is necessary to require the development of skills in working with digital technologies not only from ICT specialists, but also from all other professions, from workers to specialists employed in education, healthcare, manufacturing, etc.

Currently, there is no single definition of digital skills and digital competencies. Moreover, many researchers associate the concept of digital competencies with digital literacy, computer literacy, information literacy, etc. [8]. Thus, S.G. Pyankova, I.V. Mitrofanova, O.T. Ergunova reveal digital competence through certain components: the skills required for the functioning and discussion of digital technologies; skills in the use of digital technologies for study, for personal purposes; private digital competencies inherent in the profession [9].

In domestic and foreign theory and practice, one can find many approaches to highlighting the priority digital competencies necessary for the new economy. Thus, the top 10 key skills, which, according to analysts of the World Economic Forum, are necessary for successful work in the conditions of the fourth industrial revolution, include [10]:

- complex problem solving;

- critical thinking;

- creativity;

- people management;

- communications skills;

- coordination skills;

- interaction skills;

- emotional intelligence;

- judgment and quick of decision-making;

- service orientation;

- ability to discuss and negotiate, cognitive flexibility.

Figure 1 presents the key skills and abilities of personnel that are becoming increasingly important for the digital economy and can affect the success of business processes in any sector.

Innovative thinking is the ability to think in new ways, a creative thought process used to generate new ideas. Innovative thinking leads to results that change the way one does business, the way one builds relationships with partners. New ideas are the way to create innovations; in order to achieve a result, it is necessary to properly systematize and manage them. The generation of ideas, by its nature, is the very process of their creation, transmission, visualization, empirical modeling. In practice, the generation of ideas often occurs during brainstorming. Creative thinking and creative approach inspires new ideas to solve real problems. Digital and ICT skills make everyday tasks easier: email, website set up, electronic communication, web analytics, and more. Analytical thinking is aimed at processing a large flow of information, identifying strengths and weaknesses of the company's growth. 


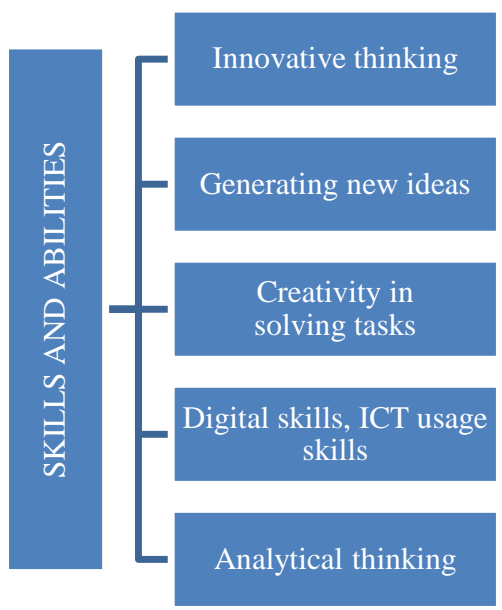

Figure 1. Skills and abilities necessary for personnel in a digital society

Source: Compiled by the authors

While the effectiveness of ICT and digital skills is well known, many companies are still not as efficient as they can be. Modern organizations need employees who know how to use ICT in the workplace.

A number of factors influence the formation of personnel necessary for the new economy (Figure 2).

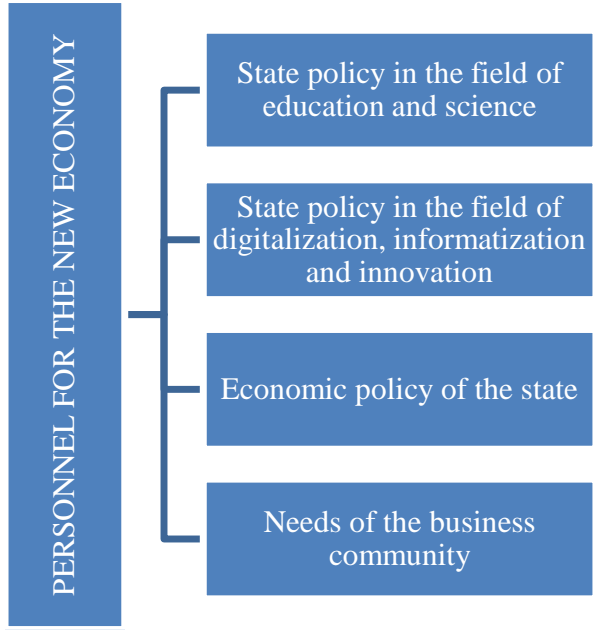

Figure 2. Factors influencing the formation of personnel for the new economy

Source: Compiled by the authors

Speaking about the state policy in the field of training personnel for the economy, it is important to note a number of federal target indicators that are being systematically implemented and are already showing results. Back in 2013, the order of the Government of the Russian Federation approved the main goals and objectives in the field of personnel training, taking into account the needs of the economy: we are talking about the federal target program "Scientific and scientific-pedagogical personnel of innovative Russia" for 2014-2020. The problem of training personnel, taking into account the needs of the Russian economy, is also reflected in the "Strategy for Innovative Development of the Russian Federation for the period up to 2020", approved by the order of the Government of the Russian Federation of December 8, 2011 No. 2227r). Decree of the Government of the Russian Federation dated April 15, 2014 No. 313 approved the state program of the Russian Federation "Information Society (2011-2020)", in order to improve the quality of life of citizens through the use of ICT. Among the key objectives of the program: ensuring the provision of services to citizens and organizations using modern ICT; development of the technical and technological basis for the formation of the information society; prevention of threats arising in the information society. The basis of the regulatory framework aimed at the development of digital education in Russia is Decree of the President of the Russian Federation No. 203 "On the Strategy for the Development of the Information Society in the Russian Federation for 2017-2030". The strategy establishes the procedure for the implementation of state policy in the field of the use of ICT by state organizations in the process of providing services to Russian citizens. Since 2018, the federal project "Digital Technologies" has been implemented, it is designed for the period 2018-2024, the key goal of this project is to ensure the technological independence of the state, the possibility of commercializing domestic research and development, as well as accelerating the technological development of Russian companies and ensuring the competitiveness of the products they develop and solutions in the market. In addition, in 2018, within the framework of the national program "Digital Economy of the Russian Federation", the federal project "Personnel for the Digital Economy" was launched, aimed at assisting citizens in mastering key digital competencies and skills, and improving digital literacy. In addition, the task is reflected, aimed at improving the education system, which should provide the digital economy with competent personnel. It is important to point out that back in July 2020, the President of the Russian Federation approved digital transformation as a national goal. This decision became the starting point in the formation of local programs at all levels of government.

Figure 3 shows some indicators of the development of the information society in Russia. 
Share of organizations using the Internet to interact with consumers

Share of organizations using the Internet

Share of organizations using personal computers

Share of the population that does not face information security problems

Share of the population using the Internet to receive state and municipal services

Share of the population using the Internet

$$
\because 2019 \square 2018-2015
$$

Figure 3. Key Indicators of the Information Society Source: [11-13]

In general, most of the indicators demonstrate the effectiveness of the policy implemented by the state. In the period between 2015 and 2019 there is an increase in the share of organizations using the Internet in interaction with consumers from $46.8 \%$ to $53.3 \%$. There is an increase in the proportion of organizations using the Internet from $88.1 \%$ in 2015 to $91.2 \%$ in 2019 , as well as an increase in the proportion of the population using the Internet [11] The share of organizations using broadband access to the Internet is growing every year. Thus, in 2010, this is $56.7 \%$ of organizations from the total number of organizations, in $2015-79.5 \%$, in $2020-93 \%$. The share of organizations with their own websites in 2010 was $28.5 \%$, in $2015-42.6 \%$, in 2019 $51.9 \%$, but in 2020 this figure decreased significantly and amounted to $44.2 \%$. There is also a decrease in the share of organizations that used electronic data exchange between their own and external information systems: in $2019-67 \%$, in $2020-54.3 \%[11,12]$.

Digitalization rapidly expanded its presence under the influence of the COVID-19 pandemic and covered all areas of Russian society, including the population, both ordinary Internet users and consumers of goods and services (health care, education, social services, through the issuance of benefits, certificates, retail trade, through online purchases of products with their subsequent delivery, etc.).

Thus, the number of the population using the

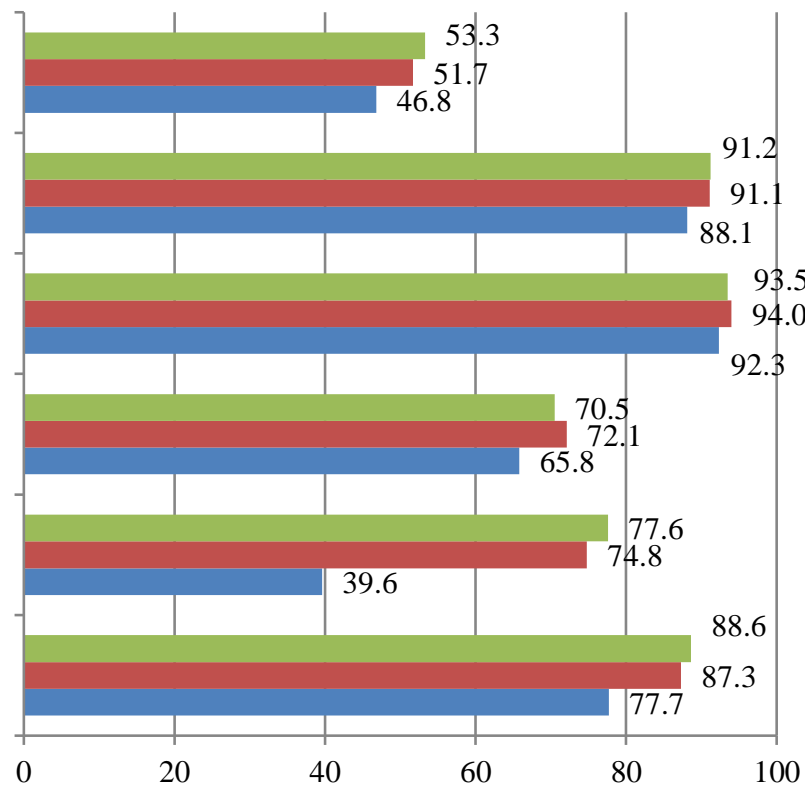

Internet to receive state and municipal services in 2015 amounted to $18.4 \%$ of the total population, in 2019 - already $57.5 \%$. In $2015,39.6 \%$ of the total population received state and municipal services, in $2019-77.6 \%$, in $2020-81.1 \%$. It is important to note that the share of people who do not use the Internet for security reasons decreased from $0.6 \%$ in 2017 to $0.4 \%$ in 2020 [11, 12]. In $2015,77.7 \%$ of the population used the Internet, in $2019-88.6 \%$, with a significant increase in the number of users in the indicated period in rural areas: from $65.5 \%$ in 2015 to $81.2 \%$ in 2019 [13].

Currently, there is a significant change in the requirements from the management of companies to the digital skills of employees. Employees of the company can achieve positive results and meet the requirements of the market only if they develop their skills that are relevant for the new economy and if they constantly improve them [14].

Thus, an extremely important place on the path of successful digital transformation of the economy belongs to the education system and retraining of personnel.

Digital transformation affects all levels of education - from preschool level to higher level and postgraduate level - and is the most important factor in its development [15]. New technologies and equipment require appropriate skills. The transformational changes observed in the economy lead to a change in jobs, the content of work. Digital 
skills need to be updated regularly for each specific workplace. In this connection, it is advisable to consider education as a process that needs to be constantly updated, to provide advanced training for both employers and employees.

Despite the government's decisive actions in the field of training, taking into account the needs of the economy and positive developments in this direction, a huge number of people still do not have basic computer literacy, despite the fact that in the period between 2015 and 2019 there is a small increase in the number population of Russia, who have basic skills in working with digital tools and technologies (Figure 4).

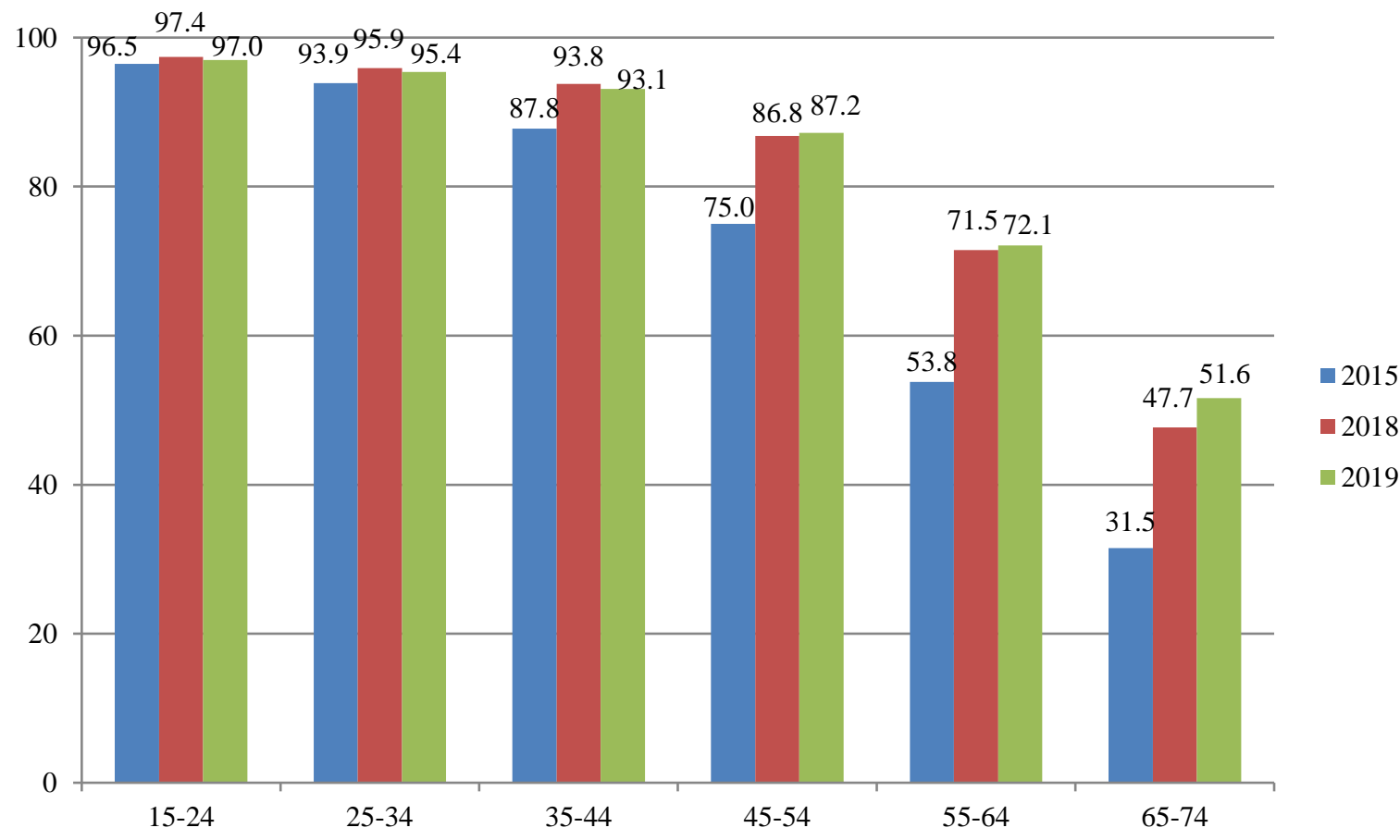

Figure 4. Population using personal computers (age groups, \%)

Source: [13]

Thus, in 2019, 57.3\% had skills in working with a text editor, and $56.4 \%$ of Russians had skills in working with e-mail [11]. At the same time, the share of the population participating in lifelong education, aged 25 to 64 , was $48.2 \%$ in 2015 (43.2\% in 2020). It is also important to note that placing the main burden on the education system in the field of developing digital skills, the number of personal computers used for educational purposes with access to the Internet (per 100 students) in higher educational institutions in 2019 amounted to 27, in 2020 - to 25 . Moreover, the share of those employed in the field of ICT in 2010-2019 was only $1.7 \%$ and only in 2020 it increased to $1.8 \%$ [12, 13].

Table 1 presents comparative data on the digital skills of the population of Russia and a number of countries.

Table 1. Comparative data on digital skills of the population of Russia and European countries (in \% of the total population of the country)

\begin{tabular}{|c|c|c|c|c|c|c|c|c|}
\hline \multirow[b]{2}{*}{ Digital skills } & \multicolumn{8}{|c|}{ Country } \\
\hline & $\begin{array}{l}\frac{\Phi}{5} \\
\frac{8}{2} \\
\text { ㅁ }\end{array}$ & ᄅ & 홍 & $\begin{array}{l}\frac{\Phi}{0} \\
\text { 닌 }\end{array}$ & 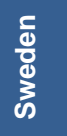 & $\frac{\text { 을 }}{\frac{\mathrm{d}}{\mathrm{E}}}$ & 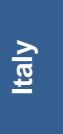 & $\frac{\text { 을 }}{\frac{0}{0}}$ \\
\hline Working with a text editor & 3 & 3 & 9 & 4 & 7 & 1 & 0 & 9 \\
\hline $\begin{array}{l}\text { Transferring files between a computer and peripheral } \\
\text { devices (digital camera, MP3 player, mobile phone) }\end{array}$ & 33 & 66 & 56 & 60 & 53 & 66 & 36 & 48 \\
\hline Working with spreadsheets & 4 & 0 & 0 & 1 & 9 & 3 & 0 & 8 \\
\hline Using software for editing photo, video and audio files & 24 & 48 & 49 & 32 & 39 & 55 & 24 & 26 \\
\hline
\end{tabular}

Source: [11] 
The data of the conducted analysis show that the level of development of digital skills of the Russian population is much lower than in many developed countries of the world. In particular, Russia lags the most in such indicators as "technology", including "promising technologies", "knowledge economy", "digital skills", "digital institutions", which leads to the need to analyze, in particular, the digital skills of the population of Russia [16].

\section{DISCUSSION}

According to the Digital Intelligence Index, which evaluates trust in the digital economy (in 90 countries across 160 indicators), Singapore is the leader (98.82), followed by the United States (89.82). China ranks 39th, Russia 49th. High positions were occupied by Great Britain, Germany and France (13th, 18th and 25th places respectively).

According to the World Digital Competitiveness Ranking 2020, which is a global digital competitiveness ranking that measures the potential and readiness of countries to adopt and explore digital technologies for economic and social transformation, the United States leads the ranking, followed by Singapore, Denmark, Sweden and Hong Kong. China ranks 16th, Germany 18th, France 24th, Russia occupies a rather low 45th position [17].

So, Russia needs to focus on national-level activities aimed at digitalizing the economy, since, according to statistics, the successful implementation of a digital economy development strategy can be hindered by a shortage of personnel. Despite the fact that all industries are undergoing changes under the influence of new technologies and business models [18], the effectiveness of the new (digital) economy, of course, largely depends on timely trained personnel that are adaptive to current transformations.

Among the main reasons for the lack of readiness of personnel for digital transformations, the following should be noted:

- the insufficient number of specialists who own ICT and digital competencies, a discrepancy between demand in the labor market and the existing supply by region;

- the lack of access or broadband access to the Internet (more often in remote areas or rural areas), as well as insufficient equipment of educational institutions, enterprises and organizations with modern computer equipment and the necessary software with high-speed and free WI-FI network, etc.;

- the insufficient level of trust on the part of many users in ICT, since personal computers store confidential information that can become a common property.

It is important to note the high level of discrepancy between existing digital skills and the demand for them, which in the coming years may lead to serious problems in the field of employment, when not the profile of a specialist, but their possession of digital skills will be important for the employer.

\section{CONCLUSION}

Digitalization today plays a crucial role in the economy of any state, therefore, it necessitates the development of a qualitatively new business model and requires a change in the format of education, healthcare and public administration, which also affects the methods and intensity of communication links between people [19].

Understanding the economic and social dimensions of digital transformation and taking appropriate responses is critical [20]. In order for the digital competencies of a modern worker to be formed on a systematic, scientific basis and to be focused on the needs of the new (digital) economy, it is necessary to single out the role of the education system as a whole at all its levels - from preschool to postgraduate. Disciplines that form digital competencies have already begun to be introduced into the educational process, but it must be done timely and adapted to each profession and line of work.

The presented statistical analysis made it possible to identify a general trend that does not link digital competencies with the ability to use various digital tools, as well as navigate technological processes.

The profile of an individual's competencies is not static, as a result of which competencies can and should develop. Upskilling and retraining based on new challenges and trends, job-specific needs, and lifelong learning opportunities will address potential future imbalances, challenges, skills gaps, and occupational and professional mismatches.

Initiatives aimed only at educational organizations will not solve the problems of developing digital competencies and their application, it is important to take into account the 
scope of work, as well as public confidence in such innovations. Whatever the problems, it is important to clearly understand and differentiate them: what skills does each specialist need? what specific skills and what means need to be learned? where exactly will digital competencies be applied?

At the state level, it is important to increase public confidence in digital technologies, since in practice there are often problems associated with the personal data leaks. It is the trust of users that often turns out to be the main criterion for the quality of a particular brand, combining such features as safety, reliability, stability, reliability and accuracy of the practical application of a particular technology [21], and it also affects the popularization of a particular product, services or innovations.

Today, there is a high dependence of users on digital technologies and, obviously, the extremely high importance of ICT and high-speed communication infrastructure for the whole society, as well as digital content and the digital economy as a whole as a factor in economic growth [22]. In this connection, there is a tendency to involve the workforce in the study of new ICT, in the process of developing digital skills. But it is important to understand that significant changes in learning models are not enough, as is the introduction of ICT in all areas. It is also necessary to take into account the impact of digital learning on the development of skills and the impact of skills on the digital transformation of organizations, and the differentiation of digital competencies for specific professions.

\section{AUTHORS' CONTRIBUTIONS}

Tatyana L. Sergeeva - statement of the research problem; formulation of the main concept of the study; development of recommendations. Dinara R. Amirova - preparation of the text of the article; literature review on the problem under study, preparation of graphic results of the study; formulation of conclusions; development of recommendations.

\section{REFERENCES}

[1] E.V. Vasilieva, V.N. Pulyaeva, V.A. Yudina, "Digital competence development of state civil servants in the Russian Federation", Business Informatics, 2018, vol. 4(46), pp. 28-42. DOI: 10.17323/1998-0663.2018.4.28.42

[2] G.P. Litvintseva, A.V. Shmakov,
E.A. Stukalenko, S.P. Petrov, "Digital component of people's quality of life assessment in the regions of the Russian Federation", Terra Economicus, 2019, vol. 17(3), pp. 107-127. (In Russ.). DOI: 10.23683/2073-6606-2019-17-3107-127

[3] "Measuring the Digital Transformation: A Roadmap for the Future", OECD Edition, Paris, 2019. DOI: $10.1787 / 9789264311992$-en

[4] OECD Digital Economy Outlook 2020. Chapter 9. Digital Innovation. Digitalization of science and innovation. Retrieved from: https://www.oecd-ilibrary.org

[5] F.M. Fossen, A. Sorgner, "Mapping the Future of Occupations: Transformative and Destructive Effects of New Digital Technologies on Jobs", Foresight and STI Governance, 2019, vol. 13(2), pp. 10-18. DOI: 10.17323/25002597.2019.2.10.18

[6] A.M. Asaliev, "Shaping workers' professional competences for digital economy needs", Vestnik of the Plekhanov Russian University of Economics, 2018, vol. 6(102), pp. 67-76. (In Russ.). DOI: 10.21686/2413-2829-2018-6-6776

[7] R.A. Baryshev, E.N. Kasyanchuk, I.A. Tsvetochkina, O.I. Babina, "Formation of digital competences of university library users", Journal of Siberian Federal University. Humanities and Social Sciences, 2021, vol. 14(9), pp. 1420-1431. DOI: 10.17516/19971370-0792

[8] M.N. Ivanenko, “Employees' Competitiveness in Russia: How to Improve Employees` Digital Competencies", Modern Information Technologies and IT-Education, 2019, vol. 15(3), pp. 775-781. DOI: 10.25559/SITITO.15.201903.775-781

[9] S.G. Pyankova, I.V. Mitrofanova, O.T. Ergunova, "Model for forming digital competencies of human resources in region in the conditions of Industry 4.0", Economics: Yesterday, Today and Tomorrow, 2021, vol. 11(6-1), pp. 39-51. (In Russ.). DOI: 10.34670/AR.2021.40.82.004

[10]T.A. Gileva, "Digital economy competences and skills: staff development program design", Bulletin USPTU. Science, Education, Economy. Series Economy, 2019, vol. 2(28), pp. 22-35. (In Russ.). DOI: 10.17122/2541-8904-2019-2-2822-35 
[11] "Information society in the Russian Federation. 2020" [Informacionnoe obshchestvo v Rossijskoj Federacii. 2020]: statistical collection, Federal State Statistics Service; National research University "Higher School of Economics", Moscow: NRU HSE, 2020. (In Russ.).

[12] "Science and innovations. Target indicators for the implementation of the Strategy for Innovative Development of the Russian Federation for the period up to 2020" (approved by Decree of the Government of the Russian Federation dated December 8, 2011 No. 2227-r) [Nauka i innovacii. Celevye indikatory realizacii Strategii innovacionnogo razvitiya RF na period do 2020 goda (utverzhdena Rasporyazheniem Pravitel'stva Rossijskoj Federacii ot 8 dekabrya 2011g. № 2227-r)]. (In Russ.). Retrieved from https://rosstat.gov.ru

[13]Federal State Statistics Service. Collection. Information Society in the Russian Federation [Federalnaya sluzhba gosudarstvennoj statistiki. Sbornik. Informacionnoe obshchestvo v Rossijskoj Federacii], 2020. (In Russ.). Retrieved from https://rosstat.gov.ru

[14] O.V. Borisova, "Model of digital and overprofessional skills of financial manager in digital economy", Financial Life, 2020, vol. 1, pp. 89-92. (In Russ.).

[15] S.I. Aksenov, R.U. Arifulina, O.A. Katushenko, T.N. Sergeeva, L.V. Romanovskaya, "Digital transformation of the educational space: new tools and technological solutions", Perspectives of Science and Education, 2021, vol. 49(1), pp. 24-43. (In Russ.). DOI: 10.32744/ pse.2021.1.2

[16]M.A. Borovskaya, M.A. Masych, T.V. Fedosova, "The potential for labor productivity growth in the context of the digital transformation", Terra Economicus, 2020, vol. 18(4), pp. 47-66. (In Russ.). DOI: 10.18522/2073-6606-2020-18-4-47-66

[17] InfoWatch Expert Analytical Center [Ekspertno-Analiticheskij centr InfoWatch]. 2021 (In Russ.). Retrieved from https://www.infowatch.ru/analytics

[18]G.Yu. Peshkova, A.Yu. Samarina, "Digital economy and recruitment potential: Strategical interconnection and prospects", The Education and Science Journal, 2018, vol. 10(20), pp. 5075. (In Russ.). DOI: 10.17853/1994-5639-201810-50-75

[19] S.P. Novikov, O.V. Mikheenko, N.A. Kulagina, O.D. Kazakov, "Digital registry of professional competences of the population drawing on distributed registries and smart contracts technologies", Business Informatics, 2018, vol. 4(46), pp. 43-53. DOI: 10.17323/19980663.2018.4.43.53

[20] A. Attrey, A. Carblanc, D. Gierten, M. Lesher, D. Pilat, A. Wyckoff, B. Kahin, "Vectors of Digital Transformation", International Organisations Research Journal, 2020, vol. 15(3), pp. 7-50. DOI: 10.17323/1996-78452020-03-01

[21]P. Purwanto, K. Kuswandi, F. Fatmah, "Interactive Applications with Artificial Intelligence Applications: The Role of Trust among Users", Foresight and STI Governance, 2020, vol. 14(2), pp. 64-75. DOI: $10.17323 / 2500-2597.2020 .2 .64 .75$

[22]M. Larionova, A. Shelepov, "Emerging Regulation for the Digital Economy: Challenges and Opportunities for Multilateral Global Governance", International Organisations Research Journal, 2021, vol. 16(1), pp. 29-63. (In Russ.). DOI: 10.17323/1996-7845-2021-0102 